CORREIA ECSS; SILVA N; COSTA MGS; WILCKEN SRS. 2015. Reproduction of Meloidogyne enterolobii in lettuce cultivars of the American group. Horticultura Brasileira 33: 147-150. DOI - http://dx.doi.org/10.1590/S0102-053620150000200002

\title{
Reproduction of Meloidogyne enterolobii in lettuce cultivars of the American group
}

\section{Érika CSS Correia; Norberto Silva; Marylia GS Costa; Silvia RS Wilcken}

UNESP-FCA, C. Postal 237, 18610-307 Botucatu-SP; erikacorreia@fca.unesp.br; nobertosv@fca.unesp.br; maryliagabriella@fca.unesp. br; srenata@fca.unesp.br

\begin{abstract}
Lettuce is the main vegetable cultivated in Brazil, in volume and in marketed value. There are ranges of diseases which may affect lettuce crops, including those caused by root-knot nematodes (Meloidogyne spp.). We evaluated the reproductive potential of Meloidogyne enterolobii in 22 lettuce cultivars. The plants were inoculated with 5,000 eggs and eventuals second stage juveniles of nematode per pot, two days after the transplanting. 'Rutgers' tomato was used as standard for inoculum viability of M. enterolobii. We evaluated, 60 days after inoculation, the gall index, egg mass index and reproduction factor (RF). The 'Ithaca', 'Raider Plus', 'RS-1397', 'L-104', 'Challenge', 'IP-11', 'Classic', 'Salinas 88', 'Vanguard 75', 'Calona' and 'Desert Queen' were resistant to M. enterolobii with RF varying from 0.22 to 0.9 , and the cultivars Lady Winterset, Robinson, Sonoma, Raider, Lucy Brown, Bnondaga, Summer Time, Taina, Sundevil and L-109 were susceptible to this nematode, with RF ranging from 1.06 to 5.73 .
\end{abstract}

Keywords: Lactuca sativa, root-knot nematodes, plant breeding.

\section{RESUMO}

Multiplicação de Meloidogyne enterolobii em cultivares de alface do grupo americano

A alface é a principal hortaliça folhosa cultivada no Brasil, tanto em volume como em valor comercializado. Em áreas de cultivo, a alface tem a sua produtividade comprometida por diversas enfermidades, incluindo as causadas pelos nematoides-das-galhas (Meloidogyne spp). Este trabalho teve como objetivo avaliar o potencial reprodutivo de Meloidogyne enterolobii em vinte e duas cultivares de alface do tipo americana. As plantas foram inoculadas com 5.000 ovos e eventuais juvenis de segundo estádio de M. enterolobii por vaso, dois dias após o transplante das cultivares. O tomateiro 'Rutgers' foi utilizado como padrão de viabilidade do inóculo de $M$. enterolobii. Foram avaliados o índice de galhas (IG), índice de massas de ovos (IMO) e fator de reprodução (FR) do nematoide, aos 60 dias após a inoculação. As cultivares Ithaca, Raider Plus, RS-1397, L-104, Challenge, IP-11, Classic, Salinas 88, Vanguard 75, Calona e Desert Queen apresentaram resistência a $M$. enterolobii, com FR variando de 0,22 a 0,9 , e as cultivares Lady, Winterset, Robinson, Sonoma, Raider, Lucy Brown, Bnondaga, Summer Time, Tainá, Sundevil e L-109 foram suscetíveis a esse nematoide, com FR variando de 1,06 a 5,73.

Palavras-chave: Lactuca sativa, nematoide-das-galhas, melhoramento genético.

(Recebido para publicação em 25 de outubro de 2013; aceito em 30 de outubro de 2014) (Received on October 25, 2013; accepted on October 30, 2014)

$\mathrm{L}$ ettuce (Lactuca sativa) is one of the most important vegetable crops grown worldwide (Sala \& Costa, 2012). Originally from temperate climate, the adaptation to high temperature regions created obstacles to growth and development, preventing the crop express all its genetic potential. In these conditions, a reduction of the crop cycle can be noticed, compromising the production due to the acceleration of plant metabolism and, consequently, the anticipation of the reproductive phase (Grangeiro et al., 2006).

However, along the years, through lettuce breeding programs, the development of cultivars adapted to different climatic conditions was noticed. Therewith, it has become possible to grow and harvest good quality lettuce throughout the year in tropical and subtropical countries, such as Brazil (Filgueira, 2008).

Despite major advances achieved through plant breeding projects, with the generation of more lettuce cultivars adapted to tropical conditions, many problems persist and a constant search for more competitive genotypes is necessary (Carvalho Filho et al., 2011). Among these problems is the parasitism in plants by nematodes genus Meloidogyne, particularly the species $M$. incognita and $M$. javanica (Charchar \&
Moita, 2005; Sikora \& Fernandez, 2005; Wilcken et al., 2005).

However, currently, M. enterolobii has caused great concern due to its high aggressiveness on several plant species, including vegetables, fruits and ornamentals (Guimarães et al., 2003; Brito et al., 2007; Kaur et al., 2007). In general, plants which show resistance to $M$. incognita, $M$. javanica and $M$. arenaria species, such as tomato and sweet pepper genotypes which carry $M i-1$ and $N$ gene, are susceptible to M. enterolobii (Moens et al., 2009; Bitencourt \& Silva, 2010).

Isolates of $M$. enterolobii from Florida were able to parasitize tomato and 
sweet pepper which showed resistance genes $M i-1$ and $N$, respectively (Brito et al., 2007). The same situation was observed in Switzerland with other tomato and sweet pepper cultivars which show these resistance genes (Kiewnick et al., 2009). In Brazil, this capacity of $M$. enterolobii to develop on a tomato carrying the $M i-1$ gene was detected in eight rootstocks (Cantu et al., 2009). Biological and histopathological studies carried out in tomato resistant ('Magnet') and susceptible ('Rutgers') to $M$. incognita, $M$. javanica and $M$. arenaria showed the capacity of $M$. enterolobii to develop nurse cells and multiply in both tomato, whereas $M$. javanica only produced nurse cells and reproduced in tomato without the $M i$ gene (Westerich et al., 2011, 2012).

Studies carried out in Cuba aiming to verify the response of different vegetable species to $M$. enterolobii, based on reproduction factor (RF), showed the resistance of 'Black Seed Simpson' lettuce to this nematode (Rodriguez et al., 2003). In Brazil, head lettuce cultivars, 'Grande Lagos 659', and the crisphead lettuce 'Mônica', were also considered resistant to this nematode, although they provide an RF greater than 1.0, as this one did not differ significantly from the reproduction factor below 1.0 of other studied cultivars (Bittencourt \& Silva, 2010).

Based on infection rate, 'Elisa', 'Luisa', 'Mirella', 'Vera' and 'Salinas 88 ' lettuce were considered moderately resistant to $M$. enterolobii, whereas 'Júlia', 'Hortência', 'Verônica', 'Grand Rapids' and 'Babá de Verão' were considered highly resistant (Melo et al., 2011). Thus, heretofore, susceptibility of lettuce cultivars to $M$. enterolobii was not verified.

The objective of this work was to determine RF for $M$. enterolobii in different head lettuce cultivars, aiming to identify sources of resistance to be used in breeding programs and options of cultivars to be used in areas infested with this nematode species.

\section{MATERIAL AND METHODS}

The experiment was carried out in a greenhouse, adjusted to not exceed $30^{\circ} \mathrm{C}$, at Universidade Estadual Júlio de Mesquita Filho, in Botucatu, São Paulo state.

The twenty two head lettuce cultivars used in this study were Lucy Brown, Robinson, Calona, Classic, Vanguard 75, Winterset, Salinas 88, Bnondaga, Ithaca, Raider Plus, Desert Queen, Sonoma, IP-11, Sundevil, Challenge, Summer Time, L-104, L-109, Tainá, Raider, Lady and RS-1397. The cultivars were provided by the Plant Breeding Program of Universidade Estadual Júlio de Mesquita Filho.

Seeds were sown in expanded polystyrene trays of 128 cells, with sterilized substrate. At 25 days after sowing, the seedlings were transplanted into definitive pots, with volumetric capacity of two liters, containing substrate \{earth, sand and organic matter $(1: 2: 1)\}$, previously autoclaved.

The population of $M$. enterolobii was obtained from the isolation of green pepper 'Silver' originated from Campos Novos Paulista. São Paulo state, and identified by the perineal pattern of females and the electrophoretic pattern of isoenzymes, according to Oliveira et al. (2012).

The multiplication of the pure population was performed in tomato cultivar 'Rutgers' in 1-liter volumetric pots, containing soil previously autoclaved. The plants were kept in greenhouse and after 60 days the roots were processed, according to Hussey \& Barker (1973) method, modified by Bonetti \& Ferraz (1981), for the extraction of eggs.

Determination of the number of eggs, and any newly hatched juveniles in suspension, was performed with the aid of Peter's blade, under light microscope. Then, lettuce was inoculated individually with 5,000 eggs and infective secondstage juveniles of the nematode studied, two days after the transplanting. The inoculation was performed placing $2 \mathrm{~mL}$ of the inoculum suspension in two holes of 3-centimeter depth in the rhizosphere of each plant. The tomato 'Rutgers' was used as inoculum viability standard in the experiment.

The completely randomized experimental design was used, with five replications, each plot consisting of one plant.

Evaluations were carried out at 60 days after inoculation. For this purpose, the root systems of cultivars were washed individually under running water, weighed after removing excess of water with a paper towel and then submitted to staining with Floxine B, to facilitate the count of egg masses (Taylor \& Sasser, 1978).

Gall index (GI) and egg masses index (EMI) found were related according to the rating scale: 0 (no galls or no egg masses); 1 (1-2 galls or egg masses); 2 (3-10 galls or egg masses); 3 (11-30 galls or egg masses); 4 (31-100 galls or egg masses) and 5 (more than 100 galls or egg masses per root) (Taylor \& Sasser, 1978). Then, root systems were processed according to the methodology proposed by Coolen \& D'Herde (1972) using $0.5 \%$ sodium hypochlorite solution instead of water, to grind the roots in a blender. The determination of the final number of eggs and newly hatched juveniles in the final suspension was performed with the aid of a Peter's blade, under a light microscope. This number (final population, FP) was used for obtaining the reproduction factor (RF) (final population of the nematode (FP) / initial population \{number of eggs used in the nematode inoculation (IP) $\}$, according to Oostenbrink (1966), that means, $R F\{R F=F P / I P\}$ equal or higher than 1.0, susceptible (S) and lower than 1.0 , resistant $(\mathrm{R})$.

\section{RESULTS AND DISCUSSION}

According to data obtained (Table 1), a difference in response to $M$. enterolobii, among head lettuce cultivars, was noticed, using as basis the nematode reproductive factor. The tomato 'Rutgers', used as susceptibility pattern, presented RF of 13.95 , proving the viability of the inoculum.

Cultivars Ithaca, Raider Plus, RS1397, L-104, Challenge, IP-11, Classic, Salinas 88, Vanguard 75, Calona and Desert Queen were unfavorable for $M$. enterolobii multiplication with reproductive factors ranging from 0.22 
Table 1. Average values of the gall index (GI), egg mass index (MI) and reproduction factor (RF) of Meloidogyne enterolobii in twenty-two lettuce cultivars \{valores médios do índice de galhas (GI), índice de massas de ovos (MI) e do fator de reprodução (RF) de Meloidogyne enterolobii em vinte e duas cultivares de alface do grupo americano . Botucatu, UNESP, 2012.

\begin{tabular}{|c|c|c|c|c|}
\hline Cultivar & $\mathbf{G I}^{1}$ & $\mathbf{M I}^{1}$ & $\mathbf{R F}^{1}$ & Reaction $^{2}$ \\
\hline Ithaca & $3.2 \mathrm{a}$ & $2.2 \mathrm{a}$ & $0.22 \mathrm{a}$ & $\mathrm{R}$ \\
\hline Raider Plus & $3.2 \mathrm{a}$ & $2.6 \mathrm{a}$ & $0.31 \mathrm{a}$ & $\mathrm{R}$ \\
\hline RS-1397 & $3.8 \mathrm{~b}$ & $3.6 \mathrm{~b}$ & $0.34 \mathrm{a}$ & $\mathrm{R}$ \\
\hline L-104 & $3.4 \mathrm{a}$ & $3.0 \mathrm{~b}$ & $0.62 \mathrm{~b}$ & $\mathrm{R}$ \\
\hline Challenge & $2.6 \mathrm{a}$ & $2.2 \mathrm{a}$ & $0.71 \mathrm{~b}$ & $\mathrm{R}$ \\
\hline IP-11 & $3.6 \mathrm{~b}$ & $3.4 \mathrm{~b}$ & $0.75 \mathrm{~b}$ & $\mathrm{R}$ \\
\hline Classic & $3.4 \mathrm{a}$ & $2.6 \mathrm{a}$ & $0.79 \mathrm{~b}$ & $\mathrm{R}$ \\
\hline Salinas 88 & $3.0 \mathrm{a}$ & $2.0 \mathrm{a}$ & $0.79 \mathrm{~b}$ & $\mathrm{R}$ \\
\hline Vanguard 75 & $3.2 \mathrm{a}$ & $2.0 \mathrm{a}$ & $0.88 \mathrm{c}$ & $\mathrm{R}$ \\
\hline Calona & $4.0 \mathrm{~b}$ & $3.0 \mathrm{~b}$ & $0.9 \mathrm{c}$ & $\mathrm{R}$ \\
\hline Desert Queen & $3.0 \mathrm{a}$ & $2.2 \mathrm{a}$ & $0.9 \mathrm{c}$ & $\mathrm{R}$ \\
\hline Lady & $3.8 \mathrm{~b}$ & $3.6 \mathrm{~b}$ & $1.06 \mathrm{c}$ & $\mathrm{S}$ \\
\hline Winterset & $3.4 \mathrm{a}$ & $1.6 \mathrm{a}$ & $1.22 \mathrm{c}$ & $\mathrm{S}$ \\
\hline Robinson & $3.8 \mathrm{~b}$ & $2.8 \mathrm{~b}$ & $1.28 \mathrm{c}$ & $\mathrm{S}$ \\
\hline Sonoma & $3.0 \mathrm{a}$ & $2.0 \mathrm{a}$ & $1.99 \mathrm{~d}$ & $\mathrm{~S}$ \\
\hline Raider & $3.2 \mathrm{a}$ & $3.2 \mathrm{~b}$ & $3.14 \mathrm{e}$ & $\mathrm{S}$ \\
\hline Lucy Brown & $3.6 \mathrm{~b}$ & $2.6 \mathrm{a}$ & $3.16 \mathrm{e}$ & $\mathrm{S}$ \\
\hline Bnondaga & $4.0 \mathrm{~b}$ & $3.2 \mathrm{~b}$ & $3.53 \mathrm{e}$ & $\mathrm{S}$ \\
\hline Summer Time & $3.2 \mathrm{a}$ & $2.6 \mathrm{a}$ & $4.47 \mathrm{f}$ & $\mathrm{S}$ \\
\hline Tainá & $3.4 \mathrm{a}$ & $2.8 \mathrm{~b}$ & $4.75 \mathrm{f}$ & $\mathrm{S}$ \\
\hline Sundevil & $3.4 \mathrm{a}$ & $2.4 \mathrm{a}$ & $4.91 \mathrm{f}$ & $\mathrm{S}$ \\
\hline L-109 & $3.8 \mathrm{~b}$ & $3.8 \mathrm{~b}$ & $5.73 \mathrm{~g}$ & $\mathrm{~S}$ \\
\hline CV (\%) & 7.62 & 10.95 & 10.19 & \\
\hline
\end{tabular}

${ }^{1}$ Means followed by same letters do not differ among themselves according to the Scott-Knott test at $5 \%$ probability (analysis from data transformed into $\sqrt{\mathrm{x}+0.5})^{2} \mathrm{R}=$ resistant $(\mathrm{RF}<1.0)$ and $\mathrm{S}=$ susceptible $(\mathrm{RF}>1.0)$, according to Oostenbrink (1966) \{médias seguidas pela mesma letra não diferem entre si pelo teste Scott-Knott a $5 \%$ de probabilidade (análise realizada a partir de dados transformados em $\sqrt{\mathrm{x}+0,5})^{2} \mathrm{R}=$ resistente $(\mathrm{FR}<1,0)$ e $\mathrm{S}=$ suscetível $(\mathrm{FR}>1,0)$, segundo Oostenbrink (1966)\}.

to 0.9 ; being considered resistant to this species of gall nematodes. The reproduction factor of $M$. enterolobii in cultivars Ithaca, Raider Plus and RS1397 were the most nearly to zero and did not differ statistically among each other, with RF of $0.22,0.31$ and 0.34 , respectively.

Susceptibility reaction to $M$. enterolobii was noticed in lettuce cultivars Lady, Winterset, Robinson, Sonoma, Raider, Lucy Brown, Bnondaga, Summer Time, Tainá, Sundevil and L-109. These cultivars provided an increase in the initial nematode population, with RF ranging
(Wilcken et al., 2005). These cultivars also behaved as resistant to $M$. enterolobii in this study. The resistance of 'Salinas 88 ' to this nematode had been reported by Melo et al. (2011).

Until then, studies of response of lettuce cultivars to $M$. enterolobii had only detected resistance to the nematode. The cultivar Black Seed Simpson, as an example, was considered resistant with RF of 0.3 and the cultivars Grande Lagos 659, head lettuce, and Mônica crisphead lettuce were considered very resistant to this nematode (Rodriguez et al., 2003; Bitencourt \& Silva, 2010). In another study, 'Elisa', 'Luisa', 'Mirella', 'Vera' and 'Salinas 88 ' were considered moderately resistant when the variable infection rate was used, whereas 'Júlia', 'Hortência', 'Verônica', 'Grand Rapids' and 'Babá de Verão' were considered highly resistant to M. enterolobii (Melo et al., 2011).

Although IG, determined by the scale of infection (grades from 1 to 5), had been used only as an auxiliary parameter to indicate the response of symptoms in plants, the authors observed that most of the tested genotypes showed relatively high GI, ranging from 2.6 to 4.0 , even those unfavorable to nematode multiplication, as an example of cultivar Calona which presented the highest average of GI (4.0), however, this cultivar was considered resistant as it did not allow nematode multiplication $(\mathrm{RF}=$ $0.9)$. This fact demonstrates that part of the population of $M$. enterolobii present in the substrate penetrated and induced parasitism, although it has not been able to complete its life cycle, the same was observed in studies with $M$. incognita race 2 in lettuce (Wilcken et al., 2005). This fact shows that GI should not be used as the main parameter for evaluating resistance of this crop; it is possible to be used only as aid in the interpretation of the final data.

Even EMI should be carefully used, since all cultivars studied as susceptible, using RF as pattern, showed EMI relatively low as it was the case mainly for cultivars Summer Time, Tainá and Sundevil which showed EMI of 2.6, 2.8 and 2.4 and RF of 4.47, 4.75 and 4.91, respectively. This fact is due to internal egg masses which were not recorded 
during EMI evaluations.

Although in literature only information on lettuce cultivars with resistance to $M$. enterolobii can be found, in this work the authors could observe that some behavior variations of head lettuce were noticed, studies on responses of different cultivars to be indicated safely being important in order to be used in fields infested with this nematode or in breeding programs.

\section{ACKNOWLEDGEMENTS}

The authors thank the Coordenação de Aperfeiçoamento de Pessoal de Nível Superior \{Coordination of Improvement of Higher Education Personnel, (CAPES) $\}$ for the financial support, and Universidade Estadual Paulista Julio de Mesquita Filho in Botucatu for their support in this work.

\section{REFERENCES}

BITENCOURT NV; SILVA GS. 2010. Reprodução de Meloidogyne enterolobii em olerícolas. Nematologia Brasileira 34: 181-183.

BONETTI JIS; FERRAZ S. 1981. Modificação do método de Hussey e Barker para extração de ovos de Meloidogyne exigua de raízes de cafeeiro. Fitopatologia Brasileira 6: 553.

BRITO JA; STANLEY JD; MENDES ML; CETINTAS R; DICKSON DW. 2007. Host status of selected cultivated plants to Meloidogyne mayaguensis in Florida. Journal of Nematology 37: 65-71.

CANTU RR; WILCKEN SRS; ROSA JMO; GOTO R. 2009. Reação de porta-enxertos comerciais de tomateiro a Meloidogyne mayaguensis. Summa Phytopathologica 35:
216-218.

CARVALHO FILHO JLS; GOMES LAA; SILVA RR; FERREIRA S; CARVALHO RRC; MALUF WR. 2011. Parâmetros populacionais e correlação entre características da resistência a nematoides das galhas em alface. Ciências Agrárias 6: 46-51.

CHARCHAR JM; MOITAAW. 2005. Metodologia para seleção de hortaliças com resistência a nematoides: Alface/Meloidogyne spp. Brasília: Embrapa Hortaliças. 8p.

COOLEN WA; D'HERDE CJ. 1972. A method for quantitative extraction of nematodes from plant tissue. Ghent: State Nematology and Entomology Research Station. 77p.

FILGUEIRA FAR. 2008. Novo manual de olericultura: agrotecnologia moderna na produção e comercialização de hortaliças. 3 ed. Viçosa: UFV. 421p.

GRANGEIRO LC; COSTA KR; MEDEIROS MA; SALVIANO AM; NEGREIROS MZ; BEZERRA NETO F; OLIVEIRA SL. 2006. Acúmulo de nutrientes por três cultivares de alface cultivadas em condições do Semiárido. Horticultura Brasileira 24: 190-194.

GUIMARÃES LMP; MOURA RM; PEDROSA EMR. 2003. Parasitismo de Meloidogyne mayaguensis em diferentes espécies botânicas. Nematologia Brasileira 27: 139-145.

HUSSEY RS; BARKER KR. 1973. A comparison of methods of collecting inocula of Meloidogyne sp., including a new technique. Plant Disease Report 57: 1025-1028.

KAUR R; BRITO JA; RICH JR. 2007. Host suitability of selected weed species to five Meloidogyne species. Nematropica 37: 107120.

KIEWNICK S; DESSIMOZ M; FRANCK L. 2009. Effects of the Mi- 1 and the N root-knot nematode-resistance gene on infection and reproduction of Meloidogyne enterolobii on tomato and pepper cultivars. Journal of Nematology 41: 134-139.

MELO OD; MALUF WR; GONÇALVES JS; GONÇALVES NETO AC; GOMES LAA; CARVALHO RC. 2011. Triagem de genótipos de hortaliças para resistência à Meloidogyne enterolobii. Pesquisa Agropecuária Brasileira
46: 829-835.

MOENS M; PERRY NR; STARR FL. 2009. Meloidogyne species - a diverse group of novel and important plant parasites. In: PERRY RN; MOENS M; STARR JL (eds). Root-knot nematodes. Wallingford: $\mathrm{CAB}$ International. p. 1-17.

OLIVEIRA CMG; TOMAZINI MD; BESSI R; INOMOTO MM. 2012. Nematoides. In: EIRAS M; GALLETI SR (org). Técnicas de Diagnóstico de Fitopatógenos. 1 ed. São Paulo: Devir Livraria, v. 1, p. 103-135.

OOSTENBRINK M. 1966. Major characteristics of the relation between nematodes and plants. Mededlingenvoor Landb Hoogeschool Wageningen 66: 3-46.

RODRIGUEZ MG; SANCHEZ L; ROWE J. 2003. Host status of agriculturally important plant familes to the root-knot nematode Meloidogyne mayaguensis in Cuba. Nematropica 33: 125-130.

SALA FC; COSTA CP. 2012. Retrospectiva e tendência da alfacicultura brasileira. Horticultura Brasileira 30: 187-194.

SIKORA A; FERNANDEZ E. 2005. Nematode parasites of vegetables. In: LUC M; SIKORA RA; BRIDGE J (eds). Plant parasitic nematodes in subtropical and tropical agriculture. Wallingford: CAB International. p. 319-392.

TAYLOR AL; SASSER JN. 1978. Biology, identification and control of root-knot nematodes (Meloidogyne species). Raleigh: North Carolina State University. 111p.

WESTERICH JN; RODELLA RA; ROSA JMO; WILCKEN SRS. 2012. Alterações anatômicas induzidas por Meloidogyne enterolobii (= M. mayaguensis) e Meloidogyne javanica em tomateiros resistentes a meloidoginose. Summa Phytopathologica 38: 192-197.

WESTERICH JN; ROSA JMO; WILCKEN SRS. 2011. Estudo comparativo da biologia de Meloidogyne enterolobii (= M. mayaguensis) e Meloidogyne javanica em tomateiros com gene Mi. Summa Phytopathologica 37: 35-41.

WILCKEN SRS; GARCIA MJDM; SILVA N. 2005. Resistência de alface do tipo americana a Meloidogyne incognita raça 2. Nematologia Brasileira 29: 267-271. 